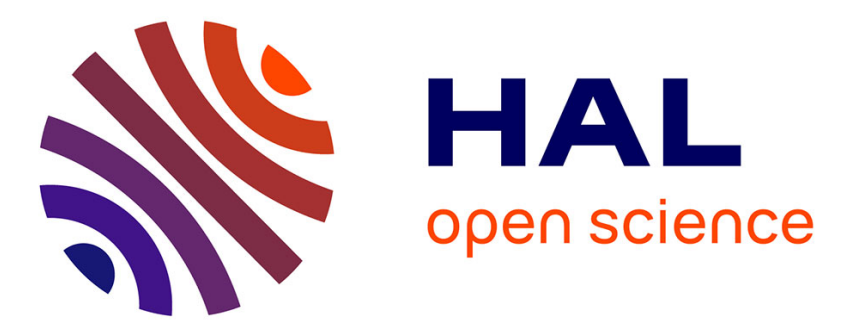

\title{
Deep groundwater flow as the main pathway for chemical outputs in a small headwater watershed (Mule Hole, South India)
}

Jean-Christophe Maréchal, Jean Riotte, Christelle Lagane, S. Subramanian, C. Kumar, Laurent Ruiz, Stéphane Audry, Mrr Varma, J.J. Braun

\section{To cite this version:}

Jean-Christophe Maréchal, Jean Riotte, Christelle Lagane, S. Subramanian, C. Kumar, et al.. Deep groundwater flow as the main pathway for chemical outputs in a small headwater watershed (Mule Hole, South India). Applied Geochemistry, 2011, 26 (S), pp.S94-S96. 10.1016/j.apgeochem.2011.03.039 . hal-00662847

\section{HAL Id: hal-00662847 https://hal.science/hal-00662847}

Submitted on 27 Jan 2012

HAL is a multi-disciplinary open access archive for the deposit and dissemination of scientific research documents, whether they are published or not. The documents may come from teaching and research institutions in France or abroad, or from public or private research centers.
L'archive ouverte pluridisciplinaire HAL, est destinée au dépôt et à la diffusion de documents scientifiques de niveau recherche, publiés ou non, émanant des établissements d'enseignement et de recherche français ou étrangers, des laboratoires publics ou privés. 


\title{
Deep groundwater flow as the main pathway for chemical outputs in a small headwater watershed (Mule Hole, South India)
}

JC Maréchal ${ }^{1,2, \square}$, J Riotte ${ }^{1,2}$, C. Lagane ${ }^{2}$, S. Subramanian ${ }^{1,3}$, C. Kumar ${ }^{1,3}$, L. Ruiz ${ }^{1,4}$, S. Audry $^{2}$, V. Murari ${ }^{1,3}$, JJ Braun ${ }^{1,2}$

${ }^{1}$ Indo-French Cell for Water Sciences, IISc-IRD Joint laboratory, Indian Institute of Science, 560012 Bangalore, India

${ }^{2}$ LMTG, Université de Toulouse, CNRS, IRD, OMP, 14 avenue Edouard Belin, 31400 Toulouse, France,

${ }^{3}$ Department of Civil Engineering, Indian Institute of Science, 560012, Bangalore, India

${ }^{4}$ INRA Agrocampus Rennes, UMR, Sol-Agronomie-Spatialisation, 65 rue de St Brieuc, CS 82415, 35042 Rennes, France

${ }^{\square}$ Corresponding Author: + $33467157998,+33467157975$, jc.marechal@brgm.fr

\begin{abstract}
This study examined the water and chemical cycles of a small forested head catchment. Application of chloride mass balance lead to the identification of a groundwater baseflow located into the active zone of the crystalline aquifer, below the weir. These findings indicate that groundwater contributes to a large part of chemical outputs at the catchment scale. This study shows that groundwater should not be ignored in most small watershed studies because this flow path and associated solutes are strongly significant for chemical balance assessment.
\end{abstract}

Keywords: weathering rate, chloride mass balance, groundwater flow, silicate rock, geochemical cycle

\section{INTRODUCTION}

Mineral weathering rates in small catchments are commonly assessed from a mass balance between solute inputs and outputs (Paces 1983; White and Brantley, 1995). Most of these studies consider that the subsurface flow is negligible and that water flows out the basin mainly as surface runoff. Therefore, it is assumed that the measurements of the discharge rate and elements concentration in surface runoff at the watershed outlet weir are sufficient to estimate the total output fluxes of elements.

The output flux due to inter-basin groundwater flow corresponds to water loss from the watershed via groundwater flow below the weir and therefore not measured at the outlet. This component of the water balance is usually poorly defined (Nichols and Verry, 2001) or even "frequently ignored altogether in catchment studies in the quiet hope that it is, in fact, zero" (Penman, 1963).

This assumption means that the limits of the hydrogeological basin correspond to those of the topographic drainage watershed, neglecting inter-basin groundwater flows. In most cases, especially in large watersheds $\left(>100 \mathrm{~km}^{2}\right)$, this assumption is correct as an average. Cross-boundary inflows and outflows statistically nullify each other. For small head catchments, this assumption is not always true. As stated in a recent special volume of Ground Water journal on the issue of small head watersheds: "Researchers studying small watersheds need to be aware that ground water flow divides do not underlie surface divides in 
many settings" (Winter et al., 2003). Moreover, ground water divides may move in response to dynamic recharge and discharge conditions.

In this paper, an extended hydrogeological analysis is performed on one small watershed located on a fractured crystalline aquifer in tropical conditions. Chloride mass balance method is implemented in order to compute groundwater flows and fluxes. In particular, we focused on the contribution of groundwater fluxes to the mass balance of weathering indicators and compared it to surface fluxes.

\section{FIELD SETTINGS}

The Mule Hole experimental watershed $\left(4.1 \mathrm{~km}^{2}\right)$ is located in the Western Ghâts, in South India (Figure 1) at $11^{\circ} 44^{\prime} \mathrm{N}$ and $76^{\circ} 27^{\prime} \mathrm{E}$ (Karnataka state, Chamrajnagar district). The study site is located in the climatic semi-humid transition area with recurrent but nonperiodic droughts, depending on monsoon rainfalls. The substratum belongs to the Precambrian Dharwar supergroup and consists of gneiss with amphibolites and quartz dykes. The elevation of the watershed ranges from 820 to $910 \mathrm{~m}$ ASL. The relief is mostly undulating with gentle slopes. It is covered by a dry deciduous forest (Barbiero et al., 2010; Barbiero et al., 2007). The thickness of the immature regolith explored by coupling geophysical, geochemical and mineralogical investigations is, on average, $17 \mathrm{~m}$ at the watershed scale, including $15 \mathrm{~m}$ of saprolite and 2 meters of soils (Braun et al., 2009).Thirteen observation wells (named P1 - P13) were drilled in the area in 2003-2004. Rainfall and runoff have been measured and sampled at a meteorological station located at Mule Hole checkpost and at the outlet (Figure 1). The stream is highly ephemeral (approximately 40 days of flow per year) with very fast recession periods and flows only in response to heavy rainfall events.

\section{RESULTS}

The measurements done in the observation wells indicate that the water table is 8 to 40 $\mathrm{m}$ deep. This is due to the high rate of evapotranspiration in this forested area (Maréchal et al., 2009). As a result, recharge rate is very low. The water table is located below the river bed during the whole year and is disconnected from the stream. The stream loses water recharging the aquifer (indirect recharge), and is similar to previous work on disconnected losing streams (Peterson and Wilson, 1988).

Recharge results from direct recharge through the regolith (Ruiz et al., 2010) and indirect recharge from the stream (Descloitres et al., 2008). The groundwater flows towards the southwest, with a baseflow identified below the weir into the saprolite and fractured shallow aquifer (Descloitres et al., 2008). The total recharge of the aquifer has been estimated using the chloride mass balance technique (Maréchal et al., 2009). Given that the water table is disconnected and there is no long-term water level fluctuation, we assume that the groundwater baseflow is equal to the natural recharge. Then, the chemical groundwater output can be determined at each observation well by multiplying element concentrations by recharge rate (Table 1). We compared these values to surface water chemical output calculated while multiplying discharge rate by element concentrations at the outlet. 


\begin{tabular}{|c|c|c|c|c|c|c|c|c|}
\hline & \multirow[t]{2}{*}{ Well } & \multirow[t]{2}{*}{$\begin{array}{c}\text { Cl GW } \\
(\mathrm{mmol} / \mathrm{l})\end{array}$} & \multirow[t]{2}{*}{$\begin{array}{l}\text { Recharge } \\
(\mathbf{m m} / \mathbf{y r})\end{array}$} & \multicolumn{5}{|c|}{$\begin{array}{l}\text { Chemical output } \\
\text { (mol/hectare/year) }\end{array}$} \\
\hline & & & & $\mathbf{N a}$ & $\mathbf{K}$ & Ca & Mg & $\mathrm{SiO} 2$ \\
\hline \multirow{12}{*}{ 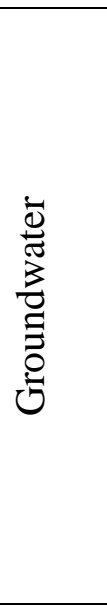 } & P11 & 98 & 250 & 748 & 267 & 1798 & 1334 & 695 \\
\hline & $\mathrm{P} 1$ & 114 & 215 & 613 & 152 & 1195 & 913 & 1364 \\
\hline & P7 & 138 & 178 & 1367 & 232 & 2141 & 2357 & 603 \\
\hline & P13 & 164 & 150 & 1032 & 173 & 1111 & 957 & 1108 \\
\hline & $\mathrm{P} 12$ & 202 & 122 & 813 & 116 & 1103 & 803 & 666 \\
\hline & P8 & 303 & 81 & 942 & 82 & 1716 & 843 & 317 \\
\hline & P10 & 477 & 52 & 857 & 31 & 181 & 140 & 437 \\
\hline & P2 & 533 & 46 & 799 & 229 & 520 & 716 & 178 \\
\hline & $\mathrm{P} 6$ & 450 & 55 & 727 & 132 & 572 & 981 & 333 \\
\hline & P5 & 528 & 47 & 582 & 100 & 726 & 482 & 351 \\
\hline & P3 & 913 & 27 & 400 & 119 & 259 & 442 & 252 \\
\hline & Average & & & 807 & 148 & 1029 & 906 & 573 \\
\hline 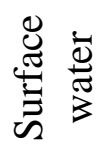 & Outlet & & $\begin{array}{l}\text { Runoff = } \\
80 \mathrm{~mm} / \mathrm{yr}\end{array}$ & 30 & 79 & 74 & 52 & 109 \\
\hline
\end{tabular}

Table 1: mass balance of the Mule Hole watershed.

The results show the high variability of chemical groundwater outputs according to wells located on various groundwater flow paths. As an average, the chemical groundwater output is much higher than the chemical output through surface runoff at the outlet: export by groundwater accounts for more than $95 \%$ of sodium, $93 \%$ of calcium, $95 \%$ of magnesium, $84 \%$ of silica. The potassium is the only tracer for which the surface export is significant, approximately $35 \%$ of the total output.

\section{DISCUSSION}

A recent study on 32 small watersheds shows that the average flow of groundwater out of the watershed is $45 \%$ of streamflow (Verry, 2003). Sometimes, this flow can be due to specific geological conditions like the existence of faults or a sedimentary basin structure. However, it can also appear in a flat crystalline aquifer where flows predominantly occur in a shallow higher-permeability zone - "active" zone - that overlies a deeper lower permeability zone hosting little flow - "inactive" zone (Maréchal, 2010). Figure 2 shows where the groundwater flow is constituted by a hierarchical pattern of flow systems within the active zone: local, intermediate, and regional according to Toth theory (Toth, 1963). Groundwater flows from recharge areas, which are associated with high groundwater levels, to discharge areas, which are associated with low groundwater levels. A local flow system develops between a topographic high (recharge area) and an adjacent topographic low (discharge area). An intermediate flow system consists of several topographic lows intervening between recharge and discharge areas. A regional flow system has its recharge area at the highest part of the groundwater basin and its discharge area at the lowest part of the basin.

The study of the mass balance of a small drainage watershed located at the head of the system (Figure $2 b$ ) necessitates to consider an extra flux corresponding to the output flux by groundwater flow $Q_{i, g w}$. Even if the flow velocities in local flow systems are often much faster 
than the flow velocity in a regional system, the flux of elements, which is highly dependent on the concentration in groundwater, may be non-negligible.

The scale effect of the problem is illustrated at Figure 2. Larger basins are statistically less subject to inter-basin groundwater flows, which generally occur in small head catchments. Therefore, groundwater should not be ignored in most small watershed studies because groundwater flow and associated solutes are significant to many of the local physical, chemical and biological processes (Rosenberry, 2003).

In such a case, the mass balance used to determine the chemical weathering fluxes for a species i must be corrected to:

$$
Q_{i, w}=Q_{i, r}+Q_{i, g w}-Q_{i, p}-Q_{i, d} \mp Q_{i, b} \mp Q_{i, e}
$$

Where $Q_{i, r}=$ runoff flux

$Q_{i, w}=$ net chemical weathering flux from bedrock, saprolite and soil layers

$Q_{i, p}=$ input flux due to atmospheric wet deposition

$Q_{i, d}=$ input flux due to atmospheric dry deposition

$Q_{i, b}=$ source/sink flux due to biomass activity

$Q_{i, e}=$ source/sink flux due to exchange by sorption/desorption in weathering profiles

$Q_{i, g w}=$ output flux due to inter-basin groundwater flow

This study has strong implications for modeling watershed scale processes - eg (Violette et al., 2010).

\section{CONCLUSION}

The study demonstrates that forest cover has impacted the water cycle and associated solute balances of this crystalline watershed. The high rate of evapotranspiration induces low recharge rate to the aquifer. Consequently, the water table is deep and disconnected from the stream. It results in deep groundwater flows below the weir which contributes for more than $90 \%$ of the total chemical outputs, and for less than $10 \%$ through surface runoff. The conclusion is that groundwater should not be ignored in most small watershed studies because groundwater flow and associated solutes are significant, if not dominant.

\section{ACKNOWLEDGMENTS}

The Mule Hole basin is part of the ORE-BVET project (Observatoire de Recherche en Environnement - Bassin Versant Expérimentaux Tropicaux, www.orebvet.fr). Apart from the specific support from the French Institute of Research for Development (IRD), the Embassy of France in India and the Indian Institute of Science, our project benefited from funding from IRD and INSU/CNRS (Institut National des Sciences de l'Univers / Centre National de la Recherche Scientifique) through the French programmes ECCO-PNRH (Ecosphère Continentale: Processus et Modélisation - Programme National Recherche Hydrologique), EC2CO (Ecosphère Continentale et Côtière) and ACI-Eau. It is also funded by the IndoFrench programme IFCPAR (Indo-French Center for the Promotion of Advanced Research W-3000). We thank the Karnataka Forest Department and the staff of the Bandipur National Park for all the facilities and support they provided. 


\section{REFERENCES}

Barbiero L., Kumar M. S. M., Violette A., Oliva P., Braun J. J., Kumar C., Furian S., Babic M., Riotte J., and Valles V. (2010) Ferrolysis induced soil transformation by natural drainage in Vertisols of sub-humid South India. Geoderma 156(3-4), 173-188.

Barbiero L., Parate H. R., Descloitres M., Bost A., Furian S., Kumar M. S. M., Kumar C., and Braun J. J. (2007) Using a structural approach to identify relationships between soil and erosion in a semi-humid forested area, South India. CATENA 70(3), 313-329.

Braun J. J., Descloitres M., Riotte J., Fleury S., Barbiero L., Boeglin J. L., Violette A., Lacarce E., Ruiz L., Sekhar M., Kumar M. S. M., Subramanian S., and Dupree B. (2009) Regolith mass balance inferred from combined mineralogical, geochemical and geophysical studies: Mule Hole gneissic watershed, South India. Geochimica Et Cosmochimica Acta 73(4), 935-961.

Descloitres M., Ruiz L., Sekhar M., Legchenko A., Braun J. J., Mohan Kumar M. S., and Subramanian S. (2008) Characterization of seasonal local recharge using electrical resistivity tomography and magnetic resonance sounding. Hydrological Processes 22(3), 384-394.

Maréchal J.-C., Varma M. R. R., Riotte J., Vouillamoz J.-M., Kumar M. S. M., Ruiz L., Sekhar M., and Braun J.-J. (2009) Indirect and direct recharges in a tropical forested watershed: Mule Hole, India. Journal of Hydrology 364(3-4), 272-284.

Maréchal J. C. (2010) Editor's message: the sunk cost fallacy of deep drilling. Hydrogeology Journal 18(2), 287-289.

Nichols D. S. and Verry E. S. (2001) Stream flow and ground water recharge from small forested watersheds in north central Minnesota. Journal of Hydrology 245(1-4), 89103.

Paces T. (1983) Rate constants of dissolution derived derived from the measurements of mass balance in hydrological catchments. Geochimica Et Cosmochimica Acta 47(11), 1855 1863.

Penman H. L. (1963) Vegetation and hydrology. In Technical Communication. Commonwealth Bureau of Soils.

Peterson D. M. and Wilson J. L. (1988) Variably saturated flow between streams and aquifers. New Mexico Water Resources Research Institute.

Rosenberry D. O. (2003) The Significance of Ground Water in Small Watershed Studies. Ground Water 41(7), 881-882.

Ruiz L., Varma M. R. R., Kumar M. S. M., Sekhar M., Maréchal J. C., Descloitres M., Riotte J., Kumar S., Kumar C., and Braun J. J. (2010) Water balance modelling in a tropical watershed under deciduous forest (Mule Hole, India); regolith matric storage buffers the groundwater recharge process. Journal of Hydrology 380(3-4), 460-472.

Toth J. (1963) A theoretical analysis of groundwater flow in small drainage basins. Journal of Geophysical Research 68, 4795-4812.

Verry E. S. (2003) Estimating Ground Water Yield in Small Research Basins. Ground Water 41(7), 1001-1004.

Violette A., Godderis Y., Maréchal J. C., Riotte J., Oliva P., Kumar M. S. M., Sekhar M., and Braun J. J. (2010) Modelling the chemical weathering fluxes at the watershed scale in the Tropics (Mule Hole, South India): Relative contribution of the smectite/kaolinite assemblage versus primary minerals. Chemical Geology 277(1-2), 42-60.

White A. F. and Brantley S. L. (1995) Chemical weathering rates of silicate minerals: An overview. In Chemical Weathering Rates of Silicate Minerals, Vol. 31, pp. 1-22. Mineralogical Soc America. 
Winter T. C., Rosenberry D. O., and LaBaugh J. W. (2003) Where Does the Ground Water in Small Watersheds Come From? Ground Water 41(7), 989-1000.

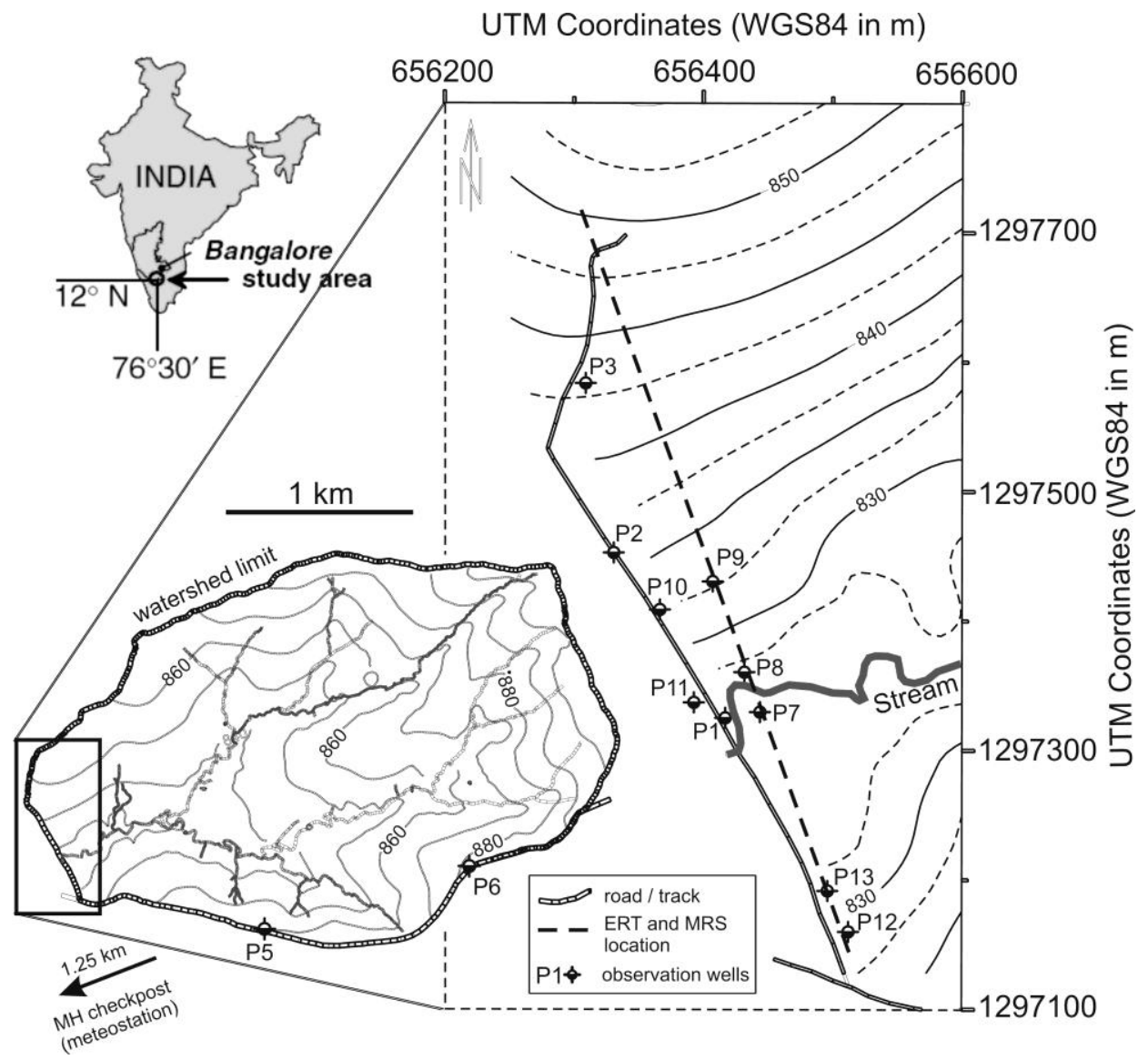

Figure 1: location map of the experimental site at the outlet of the Mule Hole watershed.

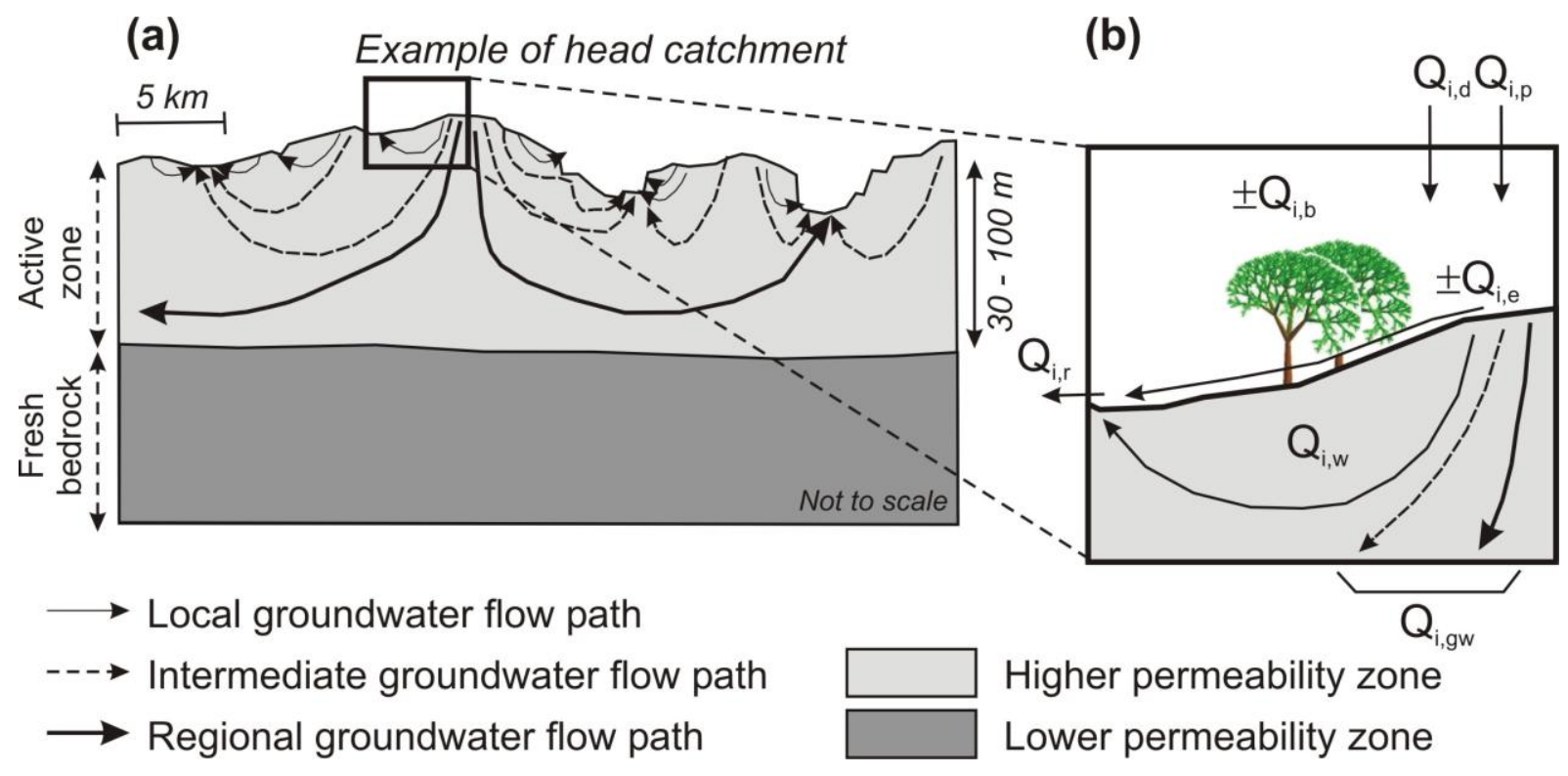

Figure 2: (a) Crystalline aquifer system showing flow paths associated with local, intermediate, and regional flow systems (modified from Toth, 1963). (b) Major fluxes of element i; symbols refer to the mass balance equation. 